\title{
Misi Kristologi Dalam Konteks Kebudayaan
}

\section{Firman Panjaitan}

Hendro H. Siburian

Sekolah Tinggi Teologi Tawangmangu

panjaitan.firman@gmail.com

hendropertama@gmail.com

\begin{tabular}{|l|l|l|}
\hline Diterima : 4 Nov. 2019 & Direvisi : 27 Nov. 2019 & Disetujui : 28 Nov. 2019 \\
\hline
\end{tabular}

\begin{abstract}
Abstrak
Seringkali kegiatan misi mengabaikan kebudayaan yang ada di masyarakat, dan hal ini yang mengakibatkan kegiatan misi menjadi tidak efektif dan bahkan menemukan kegagalan. Padahal sebuah tindakan misi harus benar-benar dapat diterima oleh masyarakat yang menjadi sasaran misi, dan jalan masuk untuk bisa hidup di tengah masyarakat adalah dengan hidup dalam kebudayaan yang ada di masyarakat tersebut. Oleh karena itu, pemahaman tentang kebudayaan sangat dibutuhkan oleh setiap orang yang hendak menjalankan misi. Terlebih kalau mau dipahami lebih dalam lagi, kebudayaan merupakan sendi dasar bagi terbentuknya kehidupan dalam sebuah komunitas atau masyarakat. Dengan kata lain, kebudayaan adalah rancang bangun kehidupan dan worldview dari sebuah masyarakat. Oleh sebab itu tindakan misi harus memahami nilai kebudayaan yang hidup di tengah masyarakat.

Namun hal ini bukan berarti bahwa misi hanya bergantung pada kebudayaan. Misi harus memiliki dasar pijakan yang kuat, sebelum bersentuhan dengan kebudayaan. Dasar pijakan yang harus dimiliki saat hendak bermisi adalah pemahaman yang benar tentang Kristologi, dengan tujuan agar tindakan misi yang dilakukan benar-benar dapat mentransformasi kebudayaan dalam nilai-nilai Kristologi. Dengan menggunakan pendekatan Kristologi untuk bermisi dalam sebuah kebudayaan, maka akan terjadi sebuah bentuk misi yang kontekstual; yang bisa dipertanggungjawabkan secara Alkitabiah sekaligus sesuai dengan konteks/budaya yang ada.
\end{abstract}

Kata kunci: Misi, kebudayaan, konteks. Masyarakat, worldview 


\section{Abstract}

The mission activities often ignore the culture in the community, and this results being ineffective and even finding failure. Whereas an act of mission must be truly acceptable to the people, who are the target of the mission, and the entrance to be able to live in the midst of society is to live in the culture that exists in that community. Therefore, an understanding of culture is needed by everyone who wants to carry out a mission. Especially if we want to be understood deeper, culture is the basic foundation for the formation of life in a community or society. In other words, culture is the design of life and worldview of the community. So, the missionary's action must understand the value of culture that lives in the midst of society.

But this does not mean that mission only depends on culture. Mission must have a strong foundation, before coming into contact with culture. The foothold that must be possessed when going to mission is a correct understanding of Christology, with the aim that the missionary actions carried out can truly transform culture into Christological values. By using the Christology approach to mission in a culture, a contextual mission form will occur; which can be justified biblically as well as in accordance with the existing context/culture.

Key words: Mission, culture, context, community, worldview 


\section{PENDAHULUAN}

Membahas tentang misiologi, kebingungan pertama yang terjadi adalah adanya benturan pengertian antara Penginjilan dan Misiologi. Seringkali kedua pemahaman ini disamakan begitu saja, seolah-olah Penginjilan adalah Misiologi. Dalam hal ini, penulis perlu terlebih dahulu meluruskan pemahaman mengenai hal ini, karena kedua hal tersebut memiliki pemahaman yang sangat jauh berbeda.

Evangelisasi dapat diterjemahkan dalam pengertian Penginjilan. Tujuan dari evangelisasi lebih tertuju pada pemenangan jiwa, pengkristenan dunia dan pelebaran/pertumbuhan gereja. Hal ini, oleh agama lain, biasa disebut dengan Pengkristenan/Kristenisasi. Hal ini tidak dapat ditampik dan dielakkan dari apa yang mereka (agama lain) tuduhkan, karena dalam kenyataannya seringkali praktik evangelisasi masih mewarnai kegiatan pelayanan Kristen. Penulis tidak memandang negatif hal penginjilan ini, karena untuk sebuah pemberitaan hal semacam itu bersifat netral dan Injil pun memang harus diperkenalkan kepada dunia ini. Namun metode yang dipakai, agaknya, perlu untuk dipertimbangkan ulang, karena metode penginjilan yang terjadi selama ini cenderung pada pemaksaan kehendak dari setiap orang pelaku penginjilan. ${ }^{1}$ Pemaksaan kehendak terjadi karena penginjil tidak memahami seluk beluk kehidupan orang yang akan di injili. Kebanyakan penginjil menghakimi objek penginjilan, penginjila juga kurang menjadi teladan dalam kehidupan sehari-hari bagi orang-orang di sekitarnya. Dan penginjil juga terkadang tidak benar-benar mengandakan karya Roh Kudus dalam penginjilannya. Akibat yang ditimbulkan dari penginjilan model ini adalah terciptanya hubungan subjek (Penginjil) dengan objek (yang menerima injil). Hal ini tidak sama dengan "cara/gaya/metode" yang diajarkan dan digunakan oleh Tuhan Yesus Kristus.

Hal yang memiliki kesamaan dengan gaya/cara/metode dari Tuhan Yesus Kristus adalah Misiologi, yang dapat diartikan dengan istilah penginjilan, karena di dalam Misiologi terkandung sebuah tugas pengutusan. Pengutusan ini diberikan kepada seluruh umat Allah yang telah

\footnotetext{
${ }^{1} \mathrm{Hal}$ ini pernah disinggung dalam pemberitaan yang diunggah dalam media on-line, Republika, dengan judul “Empat Strategi Pemurtadan Kaum Evangelis Terhadap Muslim”, tgl. 27 Juli 2010, dalam https://www.republika. co.id/berita/dunia-islam/islam-mancanegara/10/07/27/126883-empat-strategi-pemurtadan-kaum-evangelisterhadap-muslim, diakses tgl. 20 Oktober 2019.
} 
menerima keselamatan melalui Tuhan Yesus Kristus, dan mereka diutus ke dalam dunia untuk memberikan pelayanan pendamaian bagi dunia berdasarkan kuasa darah Tuhan Yesus yang telah tercurah sebagai korban pendamaian. Dalam hal ini, dikenal 4 macam misiologi, yaitu: ${ }^{2}$ pertama, Missio Ecclesiae yang dikenal sebagai bentuk pengutusan gereja, yaitu pekerjaan misioner dari jemaat Kristen sepanjang sejarah dunia; kedua, Mission Apostolorum yang dikenal dengan istilah pengutusan para rasul; ketiga, Missio Christi yang bisa diartikan sebagai pengutusan Yesus kepada para murid, tetapi juga dapat dipahami sebagai bentuk pengutusan Allah terhadap diri Yesus Kristus (bdk. Yoh. 20:21); dan keempat, Missio Dei yaitu keseluruhan pekerjaan Allah untuk keselamatan dunia. Dengan bersumber pada Missio Dei ini, maka ketiga jenis misi di atas dilaksanakan.

Dengan demikian, ladang dari misiologi ini adalah seluruh dunia dan secara khusus mengenai budaya dan kebudayaan dunia. Oleh sebab itu, sebagai langkah awal pemahaman perlu disepakati sebuah pengertian bahwa Misiologi adalah pengutusan Allah kepada seluruh umat Allah untuk bekerja bersama dengan Allah_membawa dunia pada keselamatan. ${ }^{3}$ Untuk membawa dunia pada keselamatan, maka setiap kegiatan misiologi harus dapat menyentuh budaya dan kebudayaan dunia, karena budaya/kebudayaan ini merupakan rancang bangun kehidupan manusia yang menyentuh seluruh sendi kehidupan manusia dalam berinteraksi dengan sesama. Jadi tidaklah tepat apabila dikatakan bahwa misiologi bertolak belakang/bermusuhan dengan kebudayaan, karena misiologi memiliki ladang pelayanan pada budaya manusia. Lebih baik bila dikatakan bahwa misiologi berpartner dengan budaya dan menerangi budaya tersebut. ${ }^{4}$

Dari pendapat di atas, maka dalam bermisiologi dikenal empat sikap Kristiani yang tidak memadai dalam menghadapi budaya. Keempat sikap tersebut adalah:

1. Antagonistik, yaitu sikap anti kebudayaan karena kebudayaan dianggap berdosa dan penuh dengan kejahatan. Orang Kristen harus memilih Kristus atau kebudayaan.

\footnotetext{
2 Ezra Tari, “Misiologia: Karya Allah Dalam Dunia,” last modified 2019, accessed October 20, 2019, https://www.academia.edu/8665801/ Misiologi, 1-3.

${ }^{3}$ Kees de Jong, “Misiologi Dalam Perspektif Teologi Kontekstual," Jurnal Teologi UKDW, last modified 2019, http://journal-theo.ukdw.ac.id/index.php/ gema/article/download/66/60/, diakses tgl. 20 Oktober 2019.

4 Ibid.
} 
2. Akomodatif, yaitu sikap yang memandang bahwa ada keselarasan mendasar antara iman dengan kebudayaan, sehingga iman dan kebudayaan dapat dicampur dan dilebur untuk membentuk budaya baru; dan hal ini yang biasa disebut dengan sikap sinkretisme dengan pola fruit-salad-approach (pendekatanan dalam bentuk pencampuradukan).

3. Dominatif, yaitu sikap yang memandang kebudayaan dengan rendah dan menempatkan iman Kristen lebih tinggi dari kebudayaan. Kebudayaan harus dikristenkan agar dapat menjadi budaya Kristen.

4. Dualistik, yang memandang iman terpisah dari kebudayaan. Satu sama lain tidak berhubungan dan memiliki "daerahnya" masing-masing. Ibadah selalu terpisah dari kegiatan duniawi.

Keempat sikap di atas bukanlah mewakili sikap pandang Kristiani, karena sikap Kristiani yang dianjurkan dalam menghadapi kebudayaan adalah sikap Transformtif, yaitu memandang budaya dengan kacamata positif dan kemudian menggunakan budaya sebagai pendekatan alternatif guna mengabarkan berita kesukaan dan pendamaian bagi dunia. ${ }^{5}$

\section{METODE PENELITIAN}

Dalam membahas topik Misi Kristologis dalam Konteks Kebudayaan, penulis akan menggunakan metode literary research, yaitu sebuah metode yang didasarkan atas penelitian pustaka dan literatur-literatur yang berkaitan dengan pokok bahasan. Untuk menghantar diskusi tentang topik bahasan, terlebih dahulu penulis akan menghadirkan sebuah deskripsi yang mencoba membangun hubungan antara misiologi dengan kebudayaan, dan berangkat dari pembahasan tersebut, uraian tentang topik akan disajikan secara lengkap. Dengan demikian, tulisan ini merupakan upaya penulis untuk menimbang ulang serta memberikan pengertian baru mengenai pemahaman misiologi dalam kaitannya secara langsung dengan kebudayaan. Harapan penulis, tulisan ini dapat mendorong terciptanya bentuk misiologi yang sesuai dengan konteks dan kebudayaan di Indonesia.

\footnotetext{
${ }^{5}$ E.G. Singgih, Dari Israel Ke Asia (Jakarta: BPK Gunung Mulia, 2012).21-23.
} 


\section{HASIL DAN PEMBAHASAN}

\section{Kebudayaan Sebagai Rancang Bangun Kehidupan}

Pada dasarnya manusia yang bermasyarakat, hidup dalam interaksi dengan sesamanya. Interaksi antar manusia ini didasari atas nilai-nilai bersama dan segala bentuk norma yang dipandang sebagai standar tingkah laku yang mengatur interaksi antar individu yang menunjukkan hak dan kewajiban tiap-tiap individu sebagai sarana guna mencapai tujuan bersama. Untuk menanggapi pelaksanaan norma/nilai yang telah disepakati bersama, diciptakanlah suatu tatanan baru yang berfungsi mengawasi pelaksanaan norma/nilai tersebut, dimana tatanan ini yang memberikan sanksi positif dan negatif terhadap setiap bentuk pelaksanaan nilai/norma yang diberlakukan bersama. Tatanan, yang menjadi dasar dan arah umum interaksi, inilah yang dikenal dengan sebagai kultur/budaya. ${ }^{6}$

Kultur/budaya ini kemudian dikembangkan sedemikian rupa oleh manusia menjadi tatanan yang established dalam bentuk institusi, sehingga budaya (sebagai institusi) mampu menghisap dan menjadikan manusia sebagai bagian dari kebudayaan itu sendiri (misalnya: agama, seni, dll.) Dengan terhisapnya manusia dalam kebudayaan maka setiap interaksi yang terjadi antar manusia berjalan dalam keseluruhan pola institusional-budaya yang saling berhubungan satu sama lain, dan pola inilah yang disebut dengan struktur masyarakat/sosial. Dengan kata lain struktur masyarakat/sosial adalah perngorganisasian masyarakat melalui pola aturan permainan dalam berinteraksi antar sesama. ${ }^{7}$ Dengan perkataan lain, apabila kebudayaan mau dilihat dalam hubungannya dengan turunannya, yaitu struktur sosial, maka kebudayaan dapat dikatakan sebagai sebuah sistem terpadu dari kepercayaan-kepercayaan, nilai-nilai, adat istiadat, dan dari setiap lembaga (institusi) yang mengungkapkan kepercayaan, nilai dan adat istiadat ini, yang mengikat suatu masyarakat bersama-sama dan memberikan rasa memiliki jati diri, martabat, keamanan dan kesinambungan dalam diri masyarakat tersebut. ${ }^{8}$

\footnotetext{
${ }^{6}$ A. Suryawasita, “Analisa Sosial” dalam JB Banawiratma, Kemiskinan Dan Pembebasan (Yogyakarta: Kanisius, 1994).11-12.

${ }^{7}$ Ibid.12-13

${ }^{8}$ Pengertian ini ada di dalam laporan Willowbank dari Komite Lousanne seperti yang dikutip oleh Bernard T. Adeney, Etika Sosial Lintas Budaya (Yogyakarta: Kanisius, 2000).19
} 
Untuk memperjelas pengertian tersebut, Clifford Geertz memberikan pemahaman mengenai kebudayaan sebagai sebuah sistem simbol dari makna-makna, di mana melalui sistem simbol tersebut manusia dapat memberikan makna bagi kehidupannya. Kebudayaan selalu mengacu pada suatu pola makna yang diwujudkan dalam simbol yang diturunalihkan secara historis di mana melalui pewarisan gagasan yang berbentuk simbolik tersebut manusia dapat menyampaikan, melestarikan dan mengembangkan pengetahuan mereka mengenai kehidupan. ${ }^{9}$

Secara ringkas dapat dikatakan bahwa kebudayaan merupakan sebuah rancang bangun kehidupan manusia dalam berinteraksi dengan sesamanya melalui struktur sosial yang ada dan melalui struktur sosial ini manusia, kemudian, menciptakan segala bentuk simbol yang mampu memaknai kehidupan. Dengan demikian setiap budaya yang hidup dalam struktur sosial memiliki latar belakang yang bermula dari pengalaman pribadi masing-masing lapisan masyarakat, yang pada perkembangan selanjutnya akan membentuk pengalaman tersebut menjadi sebuah pandangan umum/worldview dalam kehidupan masyarakat. Melalui pandangan worldview ini, visi dalam kehidupan bermasyarakat akan terbentuk, dan dengan terbentuknya visi maka masyarakat memiliki identitasnya. Identitas yang terbentuk dalam diri masyarakat inilah yang membedakan keberadaan antara masyarakat yang satu dengan yang lainnya. Identitas inilah yang menjadi ciri khas dari struktur sosial/masyarakat. Dengan demikian pembentukan sebuah visi tidak dapat dilepaskan dari akarnya yaitu budaya (yang sudah berkembang dalam bentuk worldview) dan struktur sosial kemasyarakatan. ${ }^{10}$

\section{Visi Kristiani Dalam Konteks Budaya}

Visi yang dihasilkan melalui worldview dari sebuah komunitas dalam struktur sosial merupakan identitas dari komunitas tersebut. Demikian juga halnya dengan komunitas Kristen yang terbentuk dalam struktur sosial yang ada di dunia ini. Kehadiran komunitas/kelompok orang Kristen di dunia, sadar atau tidak sadar, harus diakui sebagai kehadiran yang membawa identitasnya. Identitas mereka terletak pada iman mereka yang berpusat pada Kristus, dalam

\footnotetext{
${ }^{9}$ Ungkapan Clifford Geertz ini dikutip oleh Ibid. 120. Bdk. juga dengan Clifford Geertz, Kebudayaan Dan Agama (Yogyakarta: Kanisius, 2001).401, yang menekankan bahwa kebudayaan merupakan tenunan makna di mana makna-makna itu tersimpan di dalam simbol-simbol sebagai alat komunikasi. Hal yang senada juga diungkap olehDaniel I. Pals, Seven Theories of Religion (Yogyakarta: Qalam, 2001)., 401.

10 John Powel, Visi Kristiani: Kemerdekaan Yang Memerdekakan Kita (Yogyakarta: Kanisius, 1997).13-17.
} 
pengertian mereka melihat segala sesuatu yang melingkupi bidang kehidupan melalui Kristus. ${ }^{11}$ Identitas ini yang dibawa dan yang juga akan dipertaruhkan apabila mereka berhadapan dengan struktur kehidupan dan budaya yang ada di sekitar mereka.

Dalam menanggapi kehidupan di dunia, yang dalam hal ini dapat disebut sebagai konteks budaya setempat, orang Kristen tidak akan pernah mampu menghindari budaya dan struktur sosial yang ada, karena orang Kristen berada dan di utus ke dalam dunia. Sebagai komunitas yang di utus ke dalam dunia, keberadaan orang Kristen di dunia bukan bertujuan untuk menjadi sama dengan dunia, melainkan harus mampu memberikan 'teladan' kepada dunia (Yoh. 17), meskipun dunia akan menolak keberadaan setiap utusan yang dipandang 'bukan berasal dari dunia'. Dalam situasi seperti ini, diperlukan ketahanan yang begitu kokoh untuk menghadapi setiap tantangan kehidupan dimana tantangan yang paling berat, yang akan dihadapi oleh setiap orang Kristen, adalah berhadapan langsung dengan visi dunia, yaitu konteks budaya yang memiliki warna dan identitas lain dengan identitas Kristiani. Oleh sebab itu setiap orang Kristen harus memiliki keberanian untuk mempertaruhkan identitas yang telah melekat. ${ }^{12}$

Untuk bertahan dalam pertaruhan terhadap identitasnya, setiap orang Kristen harus kembali kepada visi Kristiani yang terpusat pada Kristus, dengan menekankan unsur metanoia (kesaksian) sebagai gerak langkah bagi penyataan imannya. Metanoia yang dimaksud di sini merupakan sebuah aktivitas yang menekankan keikhlasan seseorang untuk menempatkan Kristus tetap menjadi Tuhan bagi orang Kristen dan memberikan ruang bagi Tuhan untuk berkarya demi keselamatan dunia. Dan untuk penyerahan diri semacam ini diperlukan sebuah keberanian untuk menumbuhkan iman yang radikal dan kepercayaan yang mendalam terhadap Kristus sebagai Tuhan, melalui bukti ajaran dan karyaNya. Karena yang berlaku dalam visi Kristiani adalah sebuah kesadaran bahwa dalam Kerajaan Allah yang mewujud melalui Yesus Kristus, segala otoritas

\footnotetext{
${ }^{11}$ Aristarchus Sukarto, “Misi: Suatu Tinjauan Kristologis” dalam diktat ceramah Dialog Berkelanjutan: Kristen dan Islam Membangun Kehidupan Bersama, tanpa tahun, 14.

12 Dalam bahasa yang khas, Powel mengatakan, “... iman adalah alat bagi penjudi-penjudi yang bersedia untuk mempertaruhkan segala sesuatu kepada Yesus..." Lih. John Powel, Visi Kristiani: Kemerdekaan Yang Memerdekakan Kita.61.
} 
berperan pelayanan. Satu-satunya motivasi yang dapat diterima adalah cinta kasih dan satusatunya kekuasaan di dunia ini adalah kuasa cinta. ${ }^{13}$

Melalui uraian di atas, menurut penulis, pembentukan visi Kristiani sebagai identitas orang Kristen dalam menghadapi visi dunia adalah dengan cara melakukan aktivitas pelayanan bagi pendamaian dunia. Tindakan ini merupakan wujud nyata dari upaya untuk menghadirkan tandatanda Kerajaan Allah melalui karya misi dan pelayanan kepada segenap lapisan masyarakat/struktur sosial dan budaya yang ada. Maksudnya, melalui visi Kristiani ini setiap orang Kristen diharapkan dapat berperan aktif dalam mengupayakan pendamaian dunia melalui sikap dan tingkah lakunya yang mencerminkan gaya hidup yang dipenuhi oleh kasih, sukacita, damai sejahtera, dst. (seperti yang diungkap dalam Gal 5: 22-26), karena sikap tersebut merupakan cerminan hidup dari Yesus Kristus yang telah memerankan diriNya dalam sejarah dunia melalui karyaNya, dimana IA selalu menekankan bahwa pelayanannya bertujuan untuk menghadirkan Kerajaan Allah di dunia. ${ }^{14}$

\section{Iman Kristen Dalam Perspektif Kristologis}

Salah satu keunikan yang harus disadari bersama dalam mengembangkan iman Kristen adalah pemahaman tentang pribadi dan karya Yesus Kristus. Di atas sudah dihadirkan uraian yang mengatakan bahwa beriman Kristen berarti melihat segala sesuatu melalui Kristus. Namun pertanyaan yang besar yang perlu dijawab adalah, "Siapakah Yesus Kristus?" Pertanyaan ini merupakan pertanyaan yang selalu dipergumulkan oleh orang Kristen dalam rangka menetapkan gerak langkah kehidupan gereja, dan di sisi lain hal ini menjadi sangat penting bagi kehidupan orang Kristen karena menyangkut identitas mereka selaku bagian dari struktur sosial/masyarakat yang ada.

Pemahaman tentang siapa Yesus Kristus merupakan salah satu pergumulan gereja yang terbesar dewasa ini, dan ini berarti bahwa masalah mengenai Kristologi, yaitu masalah yang memuat ketegangan mengenai kemanusiaan dan Keallahan Yesus Kristus, belum dapat

\footnotetext{
${ }^{13}$ Ibid., 46-52, bdk. Dengan Karl Muller, Mission Theology (Netherlands: Steyler Verlag-Wort und Werk, 1987). 20, yang mengatakan bahwa Alkitab sangat menekankan unsur service of reconciliation dalam setiap gerak langkah kehidupan Yesus Kristus, dan inilah yang menjadi identitas Yesus yang sesungguhnya.

${ }^{14}$ Sukarto, "Misi: Suatu Tinjauan Kristologis", 16.
} 
dipecahkan dengan memuaskan. Banyak ahli yang mencoba menerangkan ketegangan yang terjadi antara kedua unsur di atas. ${ }^{15}$ Namun ketegangan itu ternyata masih terus berlangsung sampai dengan sekarang. Menghadapi perdebatan yang belum pernah selesai, penulis melihat bahwa ada 'benang merah' yang mampu untuk mengurai ketegangan yang ada. Hal itu terletak dalam ketaatan Yesus Kristus kepada Allah yang ditampakkan melalui gerak langkah pelayananNya sebagai manifestasi dari pewujudnyataan Kerajaan Allah di dunia. Setiap karya Yesus diakui sebagai "segala sesuatu yang keluar dari Bapa melalui Anak". Ada kebersatuan di antara Bapa dan Anak, sehingga kehendak Bapa di Sorga selalu mewujud secara sempurna di dalam karya Yesus Kristus. Semua karya pelayanan Yesus Kristus tertuju pada pemenuhan rencana Allah seperti yang diungkapkan melalui Kitab Perjanjian Lama, yaitu: keselamatan bagi dunia.

Dalam hal ini penulis menegaskan bahwa hal pokok dalam masalah/perdebatan mengenai aspek Kristologis di atas dapat diperkenalkan melalui penyataan yang mengatakan bahwa Yesus Kristus adalah manusia yang mengemban misi Allah bagi perdamaian dan keselamatan dunia, di mana aktivitas dan kehidupan Yesus Kristus selalu diarahkan bagi pelayanan pendamaian dunia, dan pendamaian itu sendiri berlaku dan diberlakukan bagi seluruh umat manusia. Melalui manusia Yesus, Allah mendamaikan diriNya dengan dunia, dan untuk mewujudnyatakan rencana Allah secara sempurna, Yesus Kristus ikut mengambil bagian dalam penderitaan dunia dan menjadikan diri-Nya sebagai korban pendamaian bagi dunia. ${ }^{16}$

Inilah dasar yang menyebabkan gelar Kristus (Ibr.: Mesias: yang diurapi) menjadi nyata dalam diri Yesus. Melalui gelar ini, orientasi kehidupan Yesus di dunia tidak tertuju pada diri-Nya sendiri melainkan ditujukan pada kehidupan manusia secara umum. Demikian juga dengan iman Kristen. Iman Kristen bukanlah iman yang hidup bagi dirinya sendiri melainkan ia harus hidup bagi DIA yang telah mati dan menebus dosa manusia, melalui kepeduliannya terhadap sesama (seperti yang pernah dilakukan Yesus Kristus selama la masih hidup dan berkarya di dunia). Dengan

${ }^{15}$ Perdebatan tentang keilahian dan kemanusiaan Yesus yang sudah dimulai sejak abad pertama, oleh para ahli, dapat dilihat dalam Budyanto, Mempertimbangkan Ulang Ajaran Tentang Trinitas (Yogyakarta: TPK, 2000).166-238.

${ }^{16}$ Muller, Mission Theology. 87. 
perkataan lain, peristiwa Yesus Kristus yang mengambil bagian dalam penderitaan manusia dan menjadikan diri-Nya sebagai korban pendamaian agar la dapat hidup bagi kehidupan manusia, tidak hanya bermaknakan indikatif saja melainkan juga memiliki makna imperatif terhadap kehidupan yang ditempuh oleh para murid, agar para murid dapat hidup berdamai dengan dan untuk sesama.

Untuk menjembatani ketegangan atau perdebatan mengenai aspek kemanusiaan dan Keallahan Yesus Kristus (Kristologis), penulis berpendapat bahwa kemanusiaan sejati dalam diri Yesus Kristus hanya bermakna bagi kehidupan manusia apabila dikaitkan dengan segala bentuk karya pelayanan dan pribadi Yesus Kristus yang selalu hadir dalam setiap kehidupan manusia. Sementara itu karya dan pribadi Yesus Kristus merupakan bukti dari KeallahanNya, di mana indikasi ini dapat dilihat melalui karya pelayanan dan pribadi Yesus Kristus yang hendak mencerminkan upaya Allah untuk mendamaikan diriNya dengan dunia; sehingga dengan melihat aktivitas pelayanan dan keperibadianNya, Yesus Kristus dapat dikatakan sebagai Allah sejati. ${ }^{17}$

Jika dikatakan bahwa Iman Kristen adalah iman yang memiliki perspektif Kristologis, maka hal ini dimaksudkan untuk menunjukkan tentang keunikan iman Kristen itu dalam praksis kehidupan. Iman Kristen, yang memandang segala sesuatu melalui Kristus, selalu menempatkan karya pelayanan Yesus sebagai hal terutama dalam seluruh bidang kehidupan. Dengan demikian iman Kristen hanya dapat hidup dalam bentuk pelayanan kemanusiaan yang harus dilakukan oleh setiap orang Kristen, yang diakui sebagai orang-orang utusan Yesus Kristus. Iman Kristen pun harus hidup dan mengarahkan pandangan hidupnya bagi Dia yang telah mati sebagai korban pendamaian dan hal ini harus diwujudnyatakan ke dalam bentuk refleksi kehidupan melalui aktivitas pelayanan yang berorientasi pada kesejahteraan dunia.

Dalam hal ini dapat dikatakan bahwa iman Kristen yang memiliki perspektif Kristologis adalah iman yang terarah pada pribadi Yesus Kristus, Sang Kerajaan Allah. Kerajaan Allah yang telah dipersonalisasikan dalam diri Yesus Kristus memiliki wujud dan pemahaman baru melalui pemakluman Yesus Kristus secara radikal, yaitu hidup di dalam pelayanan cinta kasih kepada seluruh dunia. Hal ini harus menjadi titik sentral dari pewartaan iman Kristen dengan tanpa

\footnotetext{
17 Ibid. 243-244.
} 

pendamaian bagi dunia dengan cara ikut terlibat dalam penderitaan dunia dan kemudian menempatkan penderitaan tersebut dalam perspektif keselamatan universal. Hal ini harus dijadikan tolok ukur utama dalam mengembangkan iman Kristen, karena Yesus Kristus telah memberikan teladan nyata dimana IA telah mengambil alih penderitaan dunia ke dalam diriNya sendiri dan melalui penderitaan tersebut IA memberikan keselamatan Allah bagi dunia. Dengan demikian, iman Kristen yang memiliki perspektif Kristologis adalah iman yang mewujudnyatakan visinya ke dalam sebuah gerak misi yang menekankan bentuk pelayanan bagi pendamaian dunia.

\section{Pemuridan dalam Perspektif Kristologis}

Sebagai upaya untuk mewujudnyatakan iman Kristen dalam kehidupan nyata, penulis mengajak untuk melihat aspek pemuridan yang pernah dilakukan oleh Yesus Kristus kepada para murid. Pemuridan yang dilakukan oleh Yesus merupakan langkah awal yang Yesus Kristus lakukan dalam upaya-Nya mengabarkan Injil Kerajaan Allah (Mark. 3:14, Yoh. 20:21). Para murid dipanggil dan dijadikan murid bukan sekadar untuk menjadi para pewaris Kerajaan Allah saja, melainkan mereka juga diberikan tugas untuk mengabarkan tentang Kerajaan Allah kepada setiap orang melalui pelayanan mereka. Di sini tampak sekali bahwa tekanan untuk bersikap altruis, yaitu sikap untuk lebih peduli terhadap orang lain, menjadi tekanan utama dalam masalah pemuridan ini. ${ }^{18}$ Tujuan pemuridan adalah untuk melibatkan manusia ke dalam unsur pelayanan pendamaian ilahi, yang sebelumnya sudah dirintis oleh Yesus Kristus. Manusia dipanggil untuk ikut ambil bagian dalam penyebaran keselamatan ilahi dan berperan aktif dalam mengupayakan pendamaian dunia. Melalui pemuridan ini, manusia diajak untuk terlibat langsung dalam upaya Yesus Kristus untuk menghadirkan tanda-tanda Kerajaan Allah di dunia.

Pemuridan yang dilakukan oleh Yesus Kristus juga merupakan sebuah bentuk persiapan bagi pengutusan. Melalui aspek pemuridan ini, para murid diajar untuk mengerti siapa Yesus Kristus bagi mereka, sekaligus diajarkan mengenai siapa orang lain/sesama bagi mereka. Penekanan terhadap masalah ini harus menjadi dasar bagi para murid, agar mereka dapat menumbuhkan bela rasa yang benar_dalam menanggapi setiap kehidupan, artinya: para murid diajarkan untuk

\footnotetext{
${ }^{18}$ Sukarto, “Misi: Suatu Tinjauan Kristologis”, 19.
} 
ikut terlibat langsung/berempati dengan penderitaan dunia. Dari titik tolak perasaan empati yang muncul itu, para murid dapat memberikan pelayanan pendamaian kepada setiap manusia bagi kesejahteraan dunia. Itulah sebabnya dalam setiap ajaranNya, Yesus Kristus selalu mempertemukan antara apa yang diungkapkan melalui ajaranNya dengan apa yang dilakukan melalui dirinya (lihat cerita tentang perumpamaan tentang orang Samaria, penyembuhan orang sakit, percakapan Yesus dengan perempuan Samaria, dll). Dengan demikian, pemuridan yang dilakukan dalam perspektif Kristologis adalah bentuk dari praksis pemuridan dengan penekanan pada karya pelayanan pendamaian bagi dunia. Melalui praksis pemuridan ini diharapkan muncul gerakan misi yang mampu menjabarkan secara langsung unsur keselamatan universal bagi dunia seperti yang telah dilakukan oleh Yesus Kristus sebelumnya, yaitu menghadirkan aspek pendamaian ilahi bagi dunia.

\section{Misi Dalam Perspektif Kristologis}

Sebagai iman yang memiliki visi dengan penekanan pada pelayanan pendamaian sebagai wujud nyata dalam menghadirkan tanda-tanda Kerajaan Allah di dunia, maka iman Kristen harus dapat menjabarkan visinya tersebut dalam sebuah gerak misi yang dapat mewakili segala keberadaan visi tersebut. Dengan kata lain, teologi hanya dapat dikatakan sebagai bentuk teologi apabila ia sungguh-sungguh berada dalam konteks setempat (kontekstual), karena pada hakikatnya teologi adalah upaya dialektis, kreatif dan eksistensial antara 'teks' Alkitab dengan konteks setempat atau antara 'kerygma' yang universal dengan kenyataan hidup yang kontekstual; maka penulis berpendapat bahwa misi yang harus dijalankan adalah misi yang selalu bersapaan dengan budaya/kultur dan struktur sosial dalam konteks setempat dengan didasarkan atas visi yang melatarbelakangi tumbuhnya gerak misi tersebut. Hal ini mengimplikasikan bahwa setiap kegiatan misi harus mampu untuk menyapa dan hidup berdampingan dengan budaya setempat.

Hidup berdampingan dengan budaya setempat bukan berarti kegiatan misi harus berubah menjadi sebuah tindakan yang bersifat sinkretistik atau terlebur ke dalam budaya sehingga identitas yang ada menjadi kabur dan tidak jelas, melainkan harus mampu masuk ke dalam budaya dengan tetap mempertahankan identitasnya. Dengan kata lain, bentuk kegiatan misi yang 
LOGIA : Jurnal Teologi Pentakosta

Vol. 1, No. 1 (Desember 2019)

ISSN : 2716-4322 (Cetak) 2716-2834 (Online)

kontekstual adalah kegiatan yang mampu menyapa dan memperkenalkan dirinya (aktivitas misi)

kepada setiap budaya setempat tanpa ada unsur untuk mengubah budaya, melainkan tetap menghargai unsur budaya yang ada. Oleh sebab itu, bentuk kegiatan misi ini lebih tepat dikatakan sebagai 'undangan' bagi kebudayaan untuk hadir dan ikut terlibat dalam perjamuan ilahi. Misi yang kontekstual merupakan upaya penginjilan kepada segenap lapisan budaya, di mana penginjilan baik yang dilakukan bukan hanya dilakukan secara verbal dan praktis saja, melainkan sudah diwujudkan melalui praksis kehidupan sehari-hari.

Mengaca pada pandangan iman yang Kristologis, maka misi pun harus memiliki perspektif Kristologis; maksudnya, kegiatan misi hanya dapat berlangsung apabila ditempatkan dalam kerangka praksis pelayanan yang bersifat mengundang setiap orang untuk ikut ambil bagian dalam Kerajaan Allah melalui bentuk pelayanan pendamaian bagi dunia.

Untuk memahami pengertian di atas, penulis mengajak untuk memperhatikan sebuah perikop yang seringkali disalahartikan oleh banyak pembaca Alkitab, perikop tersebut terdapat dalam Mat. 28: 18-20. Menurut penulis, perikop ini bukanlah perikop yang hendak menekankan kegiatan yang memaksakan orang lain masuk ke dalam lingkungan agama Kristen, melainkan memiliki penekanan yang sama sekali berbeda dengan apa yang selama ini dipahami oleh gerejagereja kebanyakan. Penulis melihat bahwa penekanan kata 'pergilah' tidak boleh terpisah dari kalimat sesudahnya. Kata 'pergilah' bukan merupakan perintah untuk pergi dengan mengemban misi (mengandung tujuan untuk) 'pemuridan, pembaptisan, dan pengajaran', tetapi harus dipahami sebagai kalimat imperatif dari sebuah kegiatan misi dengan ditambah dengan kata-kata sesudahnya. Jadi rumusannya adalah : 
LOGIA : Jurnal Teologi Pentakosta

Vol. 1, No. 1 (Desember 2019)

ISSN : 2716-4322 (Cetak) 2716-2834 (Online)
Available Online at http://sttberea.ac.id/e-journal/index.php/logia

DOI : 10.37731/log.v1i1.19

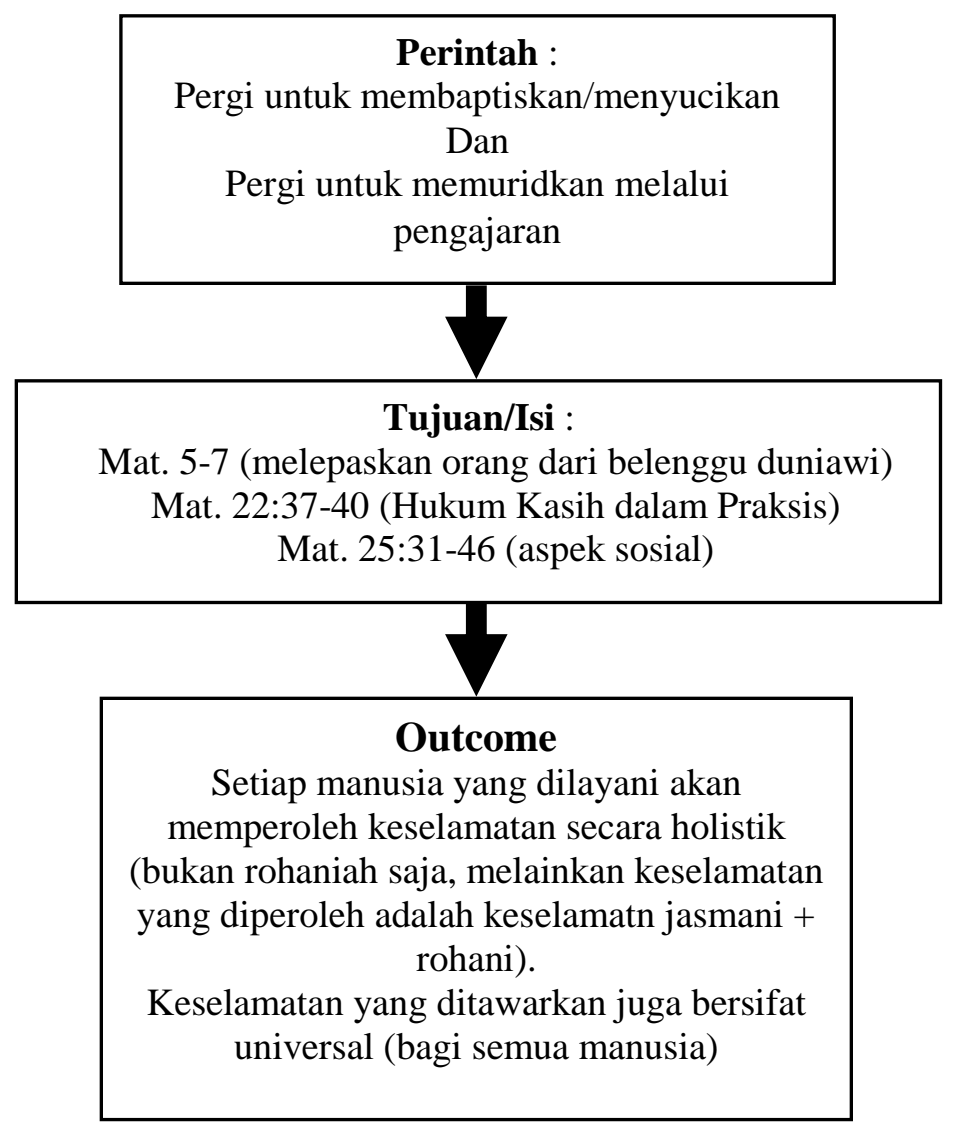

Dengan melihat bagan di atas, penulis memiliki anggapan bahwa menjalankan misi dalam perspektif Kristologis adalah menghadirkan setiap bentuk keselamatan secara holistik; maksudnya tidak berat sebelah, jadi bukan hanya menekankan unsur keselamatan secara rohaniah atau jasmaniah saja, melainkan keselamatan yang mencakup seluruh keberadaan hidup. Dimulai dari perintah agar para murid tidak diam, melainkan pergi untuk menyucikan dan mengajarkan ajaran keselamatan kepada setiap orang di dunia (tanpa ada pembedaan). Pengajaran yang diberikan adalah mengenai ajaran kebahagiaan berupa upaya melepaskan manusia dari belenggu dosa ditambah dengan ajaran-ajaran praksis mengenai kasih kepada Allah yang harus terwujud secara nyata melalui kasih kepada sesama (bdk. 1 Yoh. 4: 20) dan sekaligus memperhatikan aspek sosial, di mana pelayanan pendamaian bagi dunia bukanlah pelayanan 
yang hanya bersifat rohaniah belaka melainkan juga meliputi aspek jasmaniah. Dengan pekabaran berita bahagia ini, diharapkan segenap manusia dapat memperoleh keselamatan secara holistik.

Setiap pelayanan yang diberikan oleh Yesus Kristus adalah pelayanan yang menekankan pada keselamatan secara utuh. Yesus Kristus bukanlah manusia yang menekankan satu sisi dan mengabaikan sisi yang lain; la adalah manusia yang seimbang dan selalu menempatkan keseimbangan jiwa dan tubuh dalam porsi yang sejajar. Sehingga keselamatan dalam Kerajaan Allah yang ditawarkan oleh Yesus Kristus adalah keselamatan yang menyeluruh, bukan parsial.

\section{KESIMPULAN}

Misi dalam perspektif Kristologis, di satu sisi, adalah misi yang didasarkan atas visi yang bertujuan untuk melantunkan pelayanan pendamaian bagi dunia di mana hal ini merupakan pewujudnyataan dari upaya untuk menghadirkan tanda-tanda Kerajaan Allah melalui pelayanan yang holistik dengan sebuah penekanan agar outcome, ${ }^{19}$ yaitu kualitas yang dihasilkan dari sebuah tujuan, dapat dinikmati oleh setiap orang yang bersentuhan dengan misi itu sendiri, yang adalah keselamatan yang holistik. Di sisi lain, misi dalam perspektif Kristologis adalah misi yang mau menyentuh akar budaya dan menempatkan budaya sebagai 'partner' bagi pengembangan misi_tersebut. Hal ini didasarkan atas pemahaman mengenai kegiatan Yesus Kristus yang seringkali memakai akar budaya dalam menjalankan setiap aktivitas pelayananNya (lihat segala perangkat yang dipakai oleh Yesus yang mengikuti budaya setempat, perumpamaanperumpamaan Yesus pun seringkali mengacu pada budaya setempat, bahkan Yesus pun bertingkah laku dengan mengikuti budaya setempat).

Pada akhirnya, misi dengan perspektif Kristologis merupakan upaya untuk mengungkap pelayanan pendamaian yang didasarkan pada aspek kebenaran yang benar-benar 'BENAR' melalui sudut pandang Kristus. Dalam pengertian bahwa misi dengan perspektif Kristologis merupakan wujud nyata dari upaya untuk melakukan misi penyelamatan dunia melalui kegiatan pelayanan yang berorientasi pada kesejahteraan bagi semua orang (tanpa upaya pembedaan

${ }^{19}$ Sengaja penulis menggunakan istilah outcome, bukan output; karena dalam pengertian yang sesungguhnya istilah outcome lebih memiliki makna positif-partisipatif dan tekanannya terletak pada unsur kualitas yang dihasilkan. Sedangkan output lebih mengarah pada pengertian kuantitatif dari sebuah hasil. 
LOGIA : Jurnal Teologi Pentakosta

Vol. 1, No. 1 (Desember 2019)

ISSN : 2716-4322 (Cetak) 2716-2834 (Online)

dalam sasaran pelayanan). Dengan melalui kegiatan pelayanan bagi pendamaian dunia yang

didasarkan atas empati bagi terhadap penderitaan dunia, maka misi yang memiliki perspektif Kristologis ini hendak mengembangkan pelayanan yang mampu menyentuh semua lini kehidupan (baik di kalangan grass-root (akar rumput) atau pun di kalangan elitis) dan kemudian mengundangnya untuk masuk ke dalam pesta keselamatan ilahi. Dengan demikian setiap orang Kristen pun (termasuk gereja di dalamnya) harus menjadi piranti misi dalam mengundang setiap orang untuk berkenan masuk ke dalam pesta perjamuan Anak Domba Allah. 


\section{DAFTAR PUSTAKA}

Adeney, Bernard T. Etika Sosial Lintas Budaya. Yogyakarta: Kanisius, 2000.

Budyanto. Mempertimbangkan Ulang Ajaran Tentang Trinitas. Yogyakarta: TPK, 2000.

Clifford Geertz. Kebudayaan Dan Agama. Yogyakarta: Kanisius, 2001.

JB Banawiratma. Kemiskinan Dan Pembebasan. Yogyakarta: Kanisius, 1994.

John Powel. Visi Kristiani: Kemerdekaan Yang Memerdekakan Kita. Yogyakarta: Kanisius, 1997.

Muller, Karl. Mission Theology. Netherlands: Steyler Verlag-Wort und Werk, 1987.

Pals, Daniel I. Seven Theories of Religion. Yogyakarta: Qalam, 2001.

Sukarto, Aristarchus, “Misi: Suatu Tinjauan Kristologis” dalam diktat ceramah Dialog Berkelanjutan: Kristen dan Islam Membangun Kehidupan Bersama, tanpa tahun.

Singgih, E.G. Dari Israel Ke Asia. Jakarta: BPK Gunung Mulia, 2012.

\section{$\underline{\text { Website }}$}

Jong, Kees de. “Misiologi Dalam Perspektif Teologi Kontekstual." Jurnal Teologi UKDW. Last modified 2019. http://journal-theo.ukdw.ac.id/index.php/gema/article/download/66/60/, diakses tgl. 20 Oktober 2019.

Tari, Ezra. “Misiologia: Karya Allah Dalam Dunia.” Last modified 2019. Accessed October 20, 2019. https://www.academia.edu/8665801/ Misiologi, 1-3, . 